\title{
PRÉMIO NOBEL DE QUÍMICA 1980
}

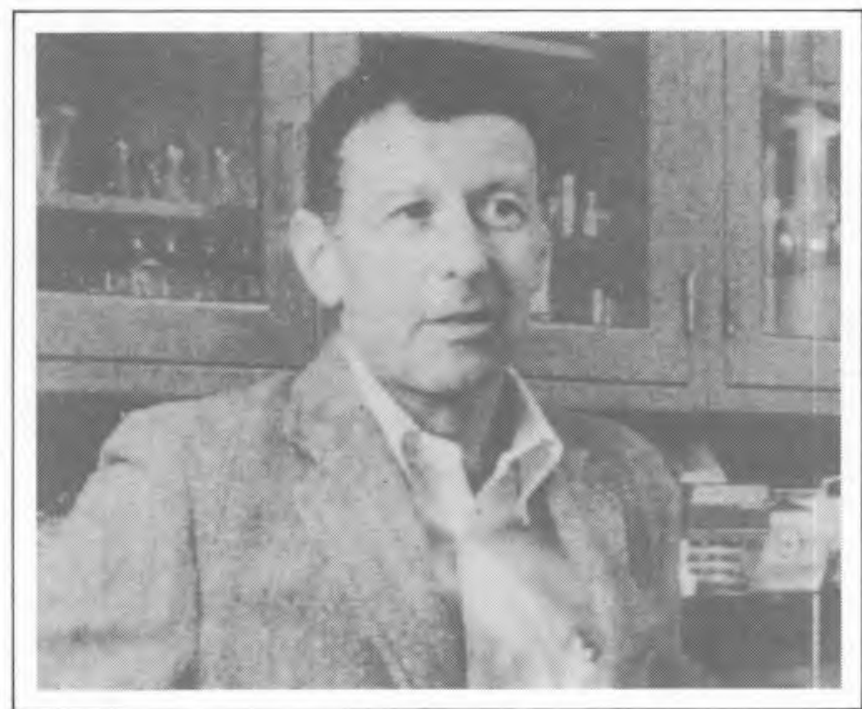

BERG

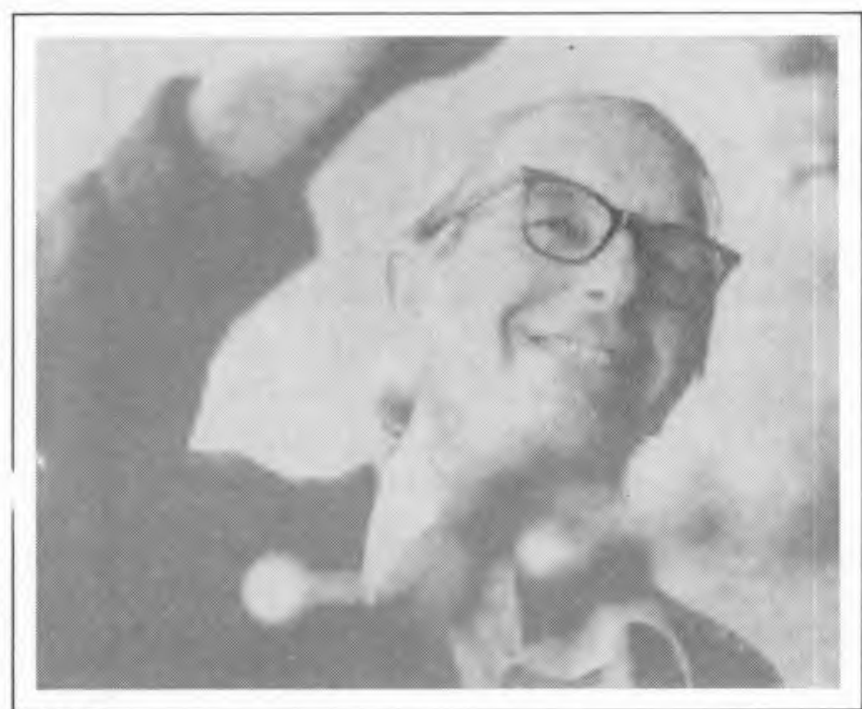

SANGER

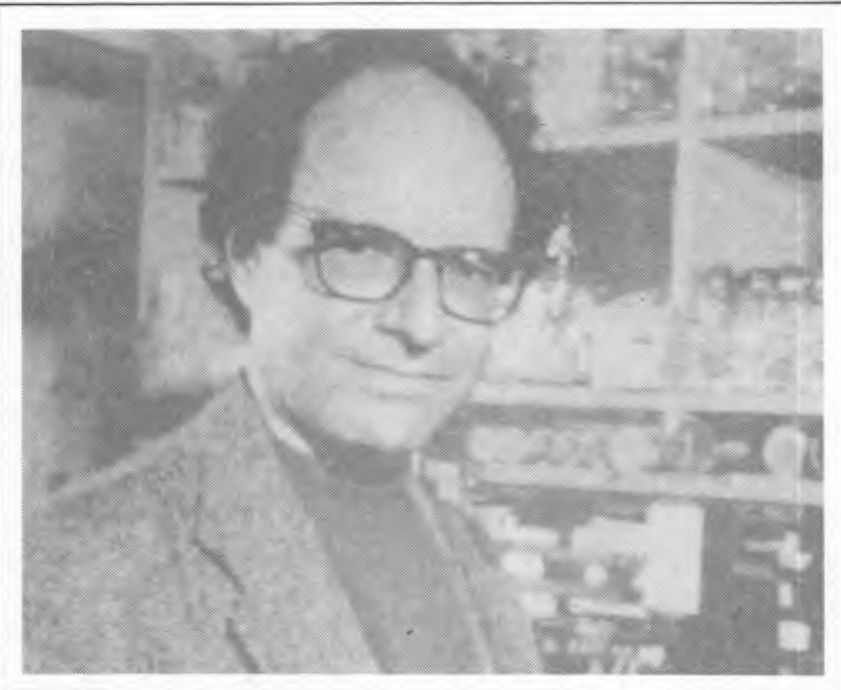

GILBERT
O prémio Nobel da Química deste ano foi partilhado por Paul Berg, da Universidade de Stanford (E.U.A.), e por Walter Gilbert e Frederick Sanger, respectivamente das Universidades de Harvard (E.U.A.) e de Cambridge (Inglaterra).

Paul Berg, numa tentativa para esclarecer por que é que as células normais se tornam cancerosas, planeou a inserção do vírus SV40 do macaco em estirpes de Escherichia coli, uma bactéria comum do tracto intestinal. Aquele vírus é capaz de causar o crescimento de tumores a partir de células de outros animais, incluindo culturas laboratoriais de células humanas. $\mathrm{O}$ projecto, iniciado em 1971, foi interrompido por Berg e outros cientistas recearem as consequências que tais experiências poderiam trazer se seres humanos viessem a ser acidentalmente contaminados. No entanto, o que determinou a atribuição do prémio Nobel a Paul Berg foram as etapas imediatamente anteriores àquela experiência: o vírus que se pretendia inserir na bactéria era um híbrido; recorrendo a enzimas capazes de cortar, reagrupar e unir ácidos nucleicos, Berg e seus colaboradores conseguiram introduzir DNA de um vírus bacteriano em genes do vírus SV40, formando um único anel fechado. Foi esta a primeira vez que os cientistas conseguiram ligar os genes de duas espécies distintas, abrindo assim o caminho para a produção de formas de vida inteiramente novas. Berg foi galardoado com o prémio Nobel por esta e outras conquistas no campo da engenharia genética.

Walter Gilbert e Frederick Sanger receberam a outra metade do prémio Nobel da Química 1980 por terem desenvolvido métodos rápidos para descodificação da estrutura genética, um instrumento chave da revolução no campo da bioquímica. Sanger fora já galardoado com o prémio Nobel da Química, em 1958, por ter elucidado a estrutura da insulina, a qual é responsável, no organismo, pelo controlo do metabolismo do açúcar.

Com os seus métodos para a determinação da sequência dos nucleótidos, que transportam a mensagem genética nas moléculas de DNA, Gilbert e Sanger contribuiram enormemente para o avanço da nova tecnologia do DNA recombinante. A técnica de Gilbert, desenvolvida em conjunto com o seu colega de Harvard Allan Maxam, é essencialmente química, utilizando reagentes para testar a presença dos diferentes nucleótidos ao longo da molécula de DNA. O método desenvolvido por Sanger é essencialmente biológico, recorrendo a um enzima para copiar nucleótidos um a um e assim proceder à sua identificação.

Estas novas técnicas facilitaram o acesso a todos os tipos de inserção de genes. Assim, pela inserção de genes apropriados, já foi possível «ensinar» bactérias a produzir interferon (substância antiviral que ajuda o organismo a proteger-se de doenças) e insulina humana. Prováveis consequências destes desenvolvimentos são a terapia de doenças congénitas por substituição de genes, a criação de novas plantas e de enzimas industriais, e possivelmente até a compreensão da problemática do cancro. 